Int. J. Morphol.,

32(1):312-316, 2014.

\title{
Bronchial tree Architecture in Mammals of Diverse Body Mass
}

\author{
Arquitectura del Árbol Bronquial en Mamíferos de Diferentes Masas Corporales
}

\author{
Adilson Monteiro* \& Ricardo Luiz Smith**
}

MONTEIRO, A. \& SMITH, R. L. Bronchial tree architecture in mammals of diverse body mass. Int. J. Morphol., 32(1):312-318, 2014.

SUMMARY: The anatomy of mammal's lung air space constitutes the bronchial tree which disposition is associated to air flux dynamics. Casts obtained from human, pig and rat lungs were studied to analyze possible differences of the bronchial tree architecture in mammals with diverse dimensions and posture. Air spaces were filled with polymers through trachea followed by acid corrosion. Tracheal and main bronchial division's diameters were measured to relate with body mass using allometry. The results revealed a dichotomic bronchial branching pattern in the human casts and a monopodial pattern in animals. In allometric relationship trachea was larger in rats, then pigs and lastly in humans, differences were statistically significant, the same occurs in right bronchus, as in the left bronchus there was no difference between rat and pig. The linear relationship between the human tracheal diameters was 1.2 times larger than the pig and 6.7 times larger than the rat; the pig tracheal diameter was 5.6 times larger than the rat. Quadruped position of the pig and rat is linked to a horizontal air way while the erect position, biped in human, correspond to a vertical air way. A big mammal shows less respiratory frequency than small mammals. Mammals with small, medium and high body mass allied to diverse posture and habits was compared revealing morphological differences in the bronchial trees as different allometric correlations between quadruped animals and human biped.

KEY WORDS: Bronchia; Anatomy; Human; Pig; Rat.

\section{INTRODUCTION}

Mammal's air ways is constituted by tubes formed by cartilaginous semi rings in the trachea and main bronchia which follows by subdivisions until bronchioles where cartilage is substituted by smooth muscle.

Terminology used to name anatomical structures is normalized by the International Anatomical Terminology (Federative Committee on Anatomical Terminology, 1998). As there is no specific rule to nominate some lung structures of rat and pig, authors utilized terms in their publications (Nakakuki, 1983, 1994). Human bronchia anatomy is well known (Williams, 1995) as the lung anatomy of the pig (Nakakuki, 1975; Hare, 1986; Dyce et al., 1997; Dondelinger et al., 1998; Mouton et al., 1999; Maina \& Gils, 2001) and rat (De Backer et al., 2009; Nakakuki, 1983; Yeh et al., 1979). Weibel \& Gomez (1962) cited that each bronchus divide in two distal bronchia corresponding to a pattern nominated dichotomic which is frequently observed in nature. In each division a bronchus (father) divided in two smaller asymmetric airways with diverse diameters. The diameters sums are larger than the father bronchia diameter (Hayward \& Reid, 1952). Weibel (1991) described an air way model for bronchial tree where terminal branches are completely identical. This simplification becomes attractive in the point of view of fluid mechanic calculation while its use is limited in some conditions. The air way model with natural asymmetry, as proposed by Horsfield (1990), is more realistic, but are inadequate when branching asymmetry and spatial distribution of airways cannot be neglected, as is the case in the rat monopodial pattern (Einstein et al., 2008) and dog lungs (Wang \& Kraman, 2004). The human bronchial tree different from the rat and dog, has a bipodial (Einstein et al.) or dichtomic branching (Patra, 1986).

Mammal respiratory physiology and airway spaces are adapted to the body mass and behavior. Dependency

\footnotetext{
* Structural and Functional Biology Program, Universidade Federal de São Paulo, Brasil.

** Departamento de Morfologia e Genética, Escola Paulista de Medicina, Universidade Federal de São Paulo Rua Botucatu 740, CEP 04023-900, São Paulo, SP, Brasil.
} 
between body dimensions and conductive bronchial tree was studied in four rodent species of Miomorfa suborder by means of allometry. Those rodents similar to rats show distinct weight and dimensions (Valerius, 1996). The author concluded that in the relatively larger airways there was a diminished resistance with a diminished body mass that is balanced in small mammals with an increased respiratory frequency.

It is a challenge to develop mathematical models with precise geometric representations to realistically reflect the animal respiratory physiology to simulate flux and fluid conditions. It is suitable to study comparative anatomy of the bronchial tree of mammals featuring dimensions and variable habits (De Backer et al.).

Animals usually used in experimental studies that involve lung physiology and bronchial tree architecture have different dimensions and habits. Comparison between bronchial tree of animals used as models and humans is necessary to understanding the validity of the functional studies. The objective of this study is to describe the bronchial tree geometry of mammals with different body mass and habits and to determine tracheal and bronchial diameters related to body mass.

\section{MATERIAL AND METHOD}

The sample includes 40 tracheobronchial tree casts for anatomic description, of these 9 are of adult humans, 8 of pigs and 9 of rats used for diameters measures. The investigation was approved by the Ethic Committee for Research of the Universidade Federal de São Paulo and São Paulo Hospital, Brazil, control number CEP 1463/11. The procedure was the same to obtain airspaces casts. Air spaces were filled with methacrylate polymers through trachea followed by $37 \%$ cloridric acid corrosion. Human lungs with trachea proceeding of necropsy from corpses without respiratory pathology that weighed between 65 to $75 \mathrm{~kg}$. To prepare the pig bronchial tree, animals of breed Landrace weighing around $30 \mathrm{~kg}$ and aged between 4 and 6 months, were anesthetized prior the sacrifice. Anesthesia was performed with Pavulon ${ }^{\circledR}(0.1 \mathrm{mg} / \mathrm{kg}$ intravenous $)$, Ketamine ${ }^{\circledR}(0.25 \mathrm{mg} / \mathrm{kg})$, acepromazine $1 \%(0.25 \mathrm{ml} / \mathrm{kg})$. Sacrifice was performed with intravenous injection of 20 $\mathrm{ml} 19.1 \%$ potassium chloride and sodium pentobarbital (3 $\mathrm{mg} / \mathrm{kg}$ ). Wistar rats weighing between $250 \mathrm{~g}$ and $350 \mathrm{~g}$ aged 4 to 6 months were sacrificed in a $70 \%$ carbon dioxide chamber. Some rat casts were made with silicone rubber. Air ways diameters were measured in digital photographs magnified and scale adjusted using the program ImageJ. To compare the relationship between trachea and main bronchia with body mass an allometric study was carried out. Body mass was considered as the medium weight of the subjects: $300 \mathrm{~g}$ for rats, $30 \mathrm{~kg}$ for pigs and $70 \mathrm{~kg}$ for humans. Data were transformed in logarithms and regressed with minimum square technique. After that measurements variance analysis and Sidak's test $\mathrm{f}$ multiple comparisons were made.

\section{RESULTS}

Bronchial division pattern is dissimilar among the studied specimens. Human bronchial tree shows division with dichotomic pattern (each bronchus divided in two distal bronchia) while in the pig and rat lungs followed a monopodial pattern (every secondary bronchus arose from each longitudinal main bronchus) (Fig. 1).

Figures 2 to 7 and respective legends show the main bronchial tree division's schemes and nomenclature with correspondent casts obtained from the specimens. Diameters of trachea and main bronchia are indicated in Table I.
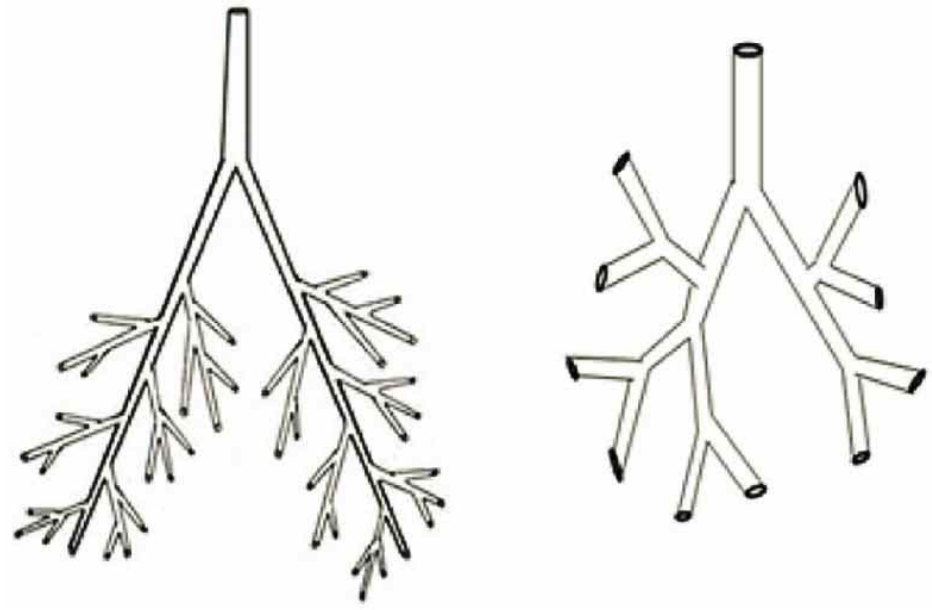

Fig. 1. Bronchial tree pattern: left monopodial and right dichotomic. 


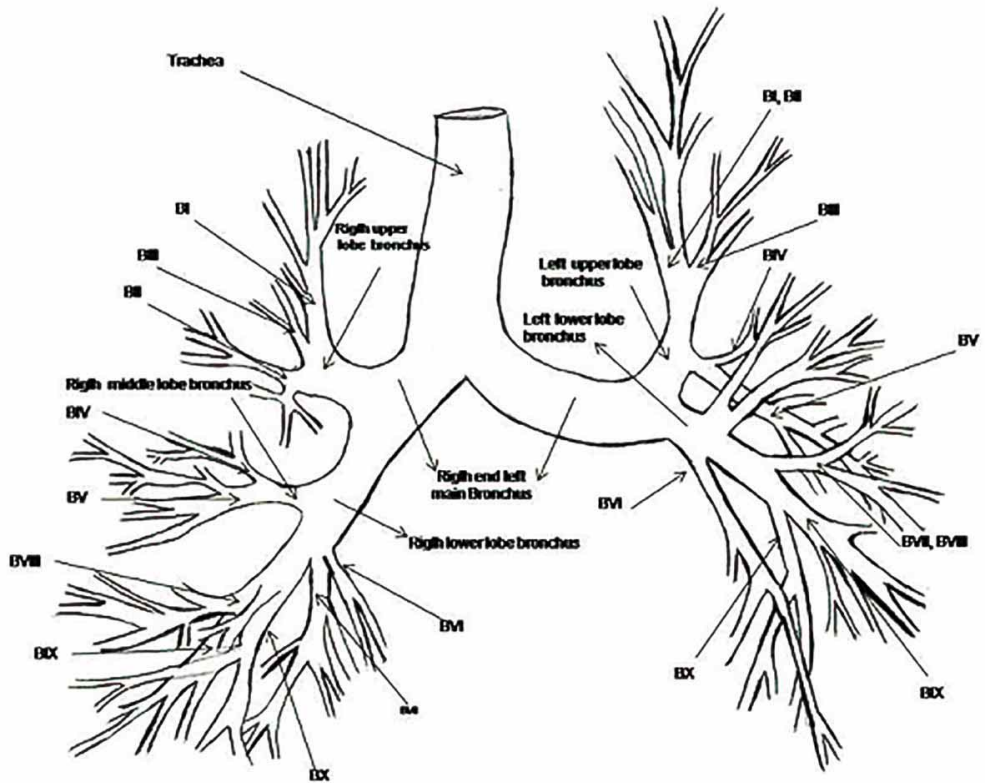

Fig. 2. Scheme and nomenclature of the human bronchial tree. Right: Main bronchus, Superior lobar bronchus, Segmental bronchi bI, bII, bIII, Middle lobar bronchus, Segmental bronchi bIV, bV, Inferior lobar bronchus and Segmental bronchi bVI, bVII, bVIII, bIX, bX. Left: Main bronchus, Superior bronchus, Segmental bronchi bI, bII, bIII, bIV, bV, Inferior lobar bronchus and Segmental bronchi bVI, bVII, bVIII, bIX, bX.

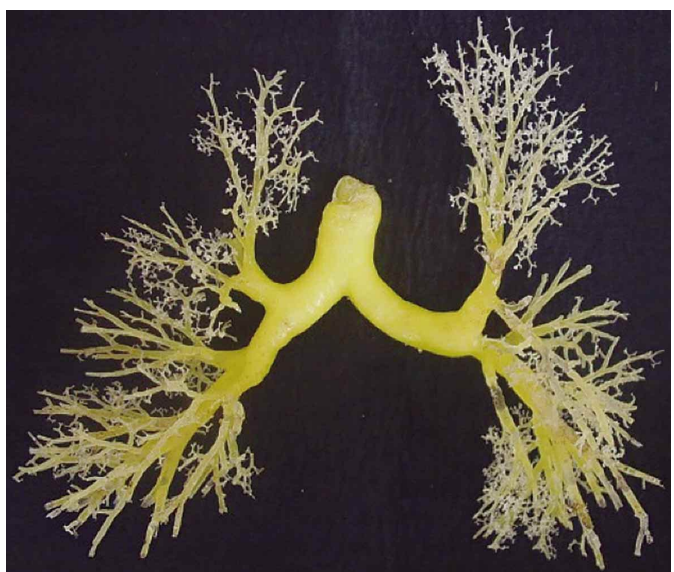

Fig. 3. Metacrilate resin casting of human bronchial tree $(\mathrm{bar}=1 \mathrm{~cm})$.

\section{TRACHEAL BRONCHUS}

\section{RIGHT MAIN BRONCHUS}
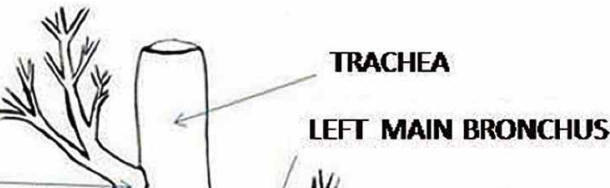

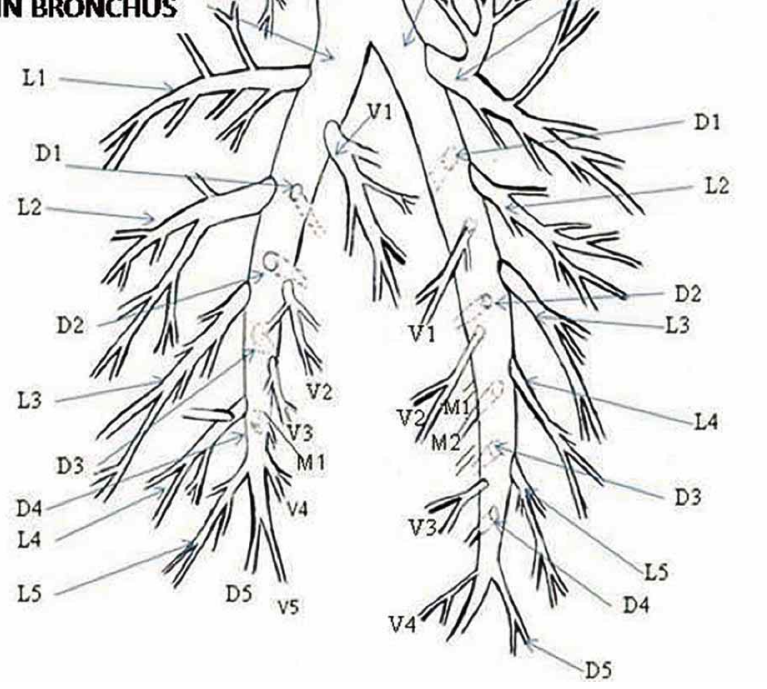

Fig. 4. Scheme and nomenclature of the pig bronchial tree. Traqueal bronchus (cranial lobar). Right: Main bronchus, Lateral 11, 12, 13, 14, 15, Dorsal d1, d2, d3, d4, Ventral v1, v2, v3, v4, v5 and Medial m1. Left: Main bronchus, Lateral 11, 12, 13, 14, 15, Dorsal d1, d2, d3, d4, d5, Ventral v1, v2, v3, v4 and Medial m1, m2. 


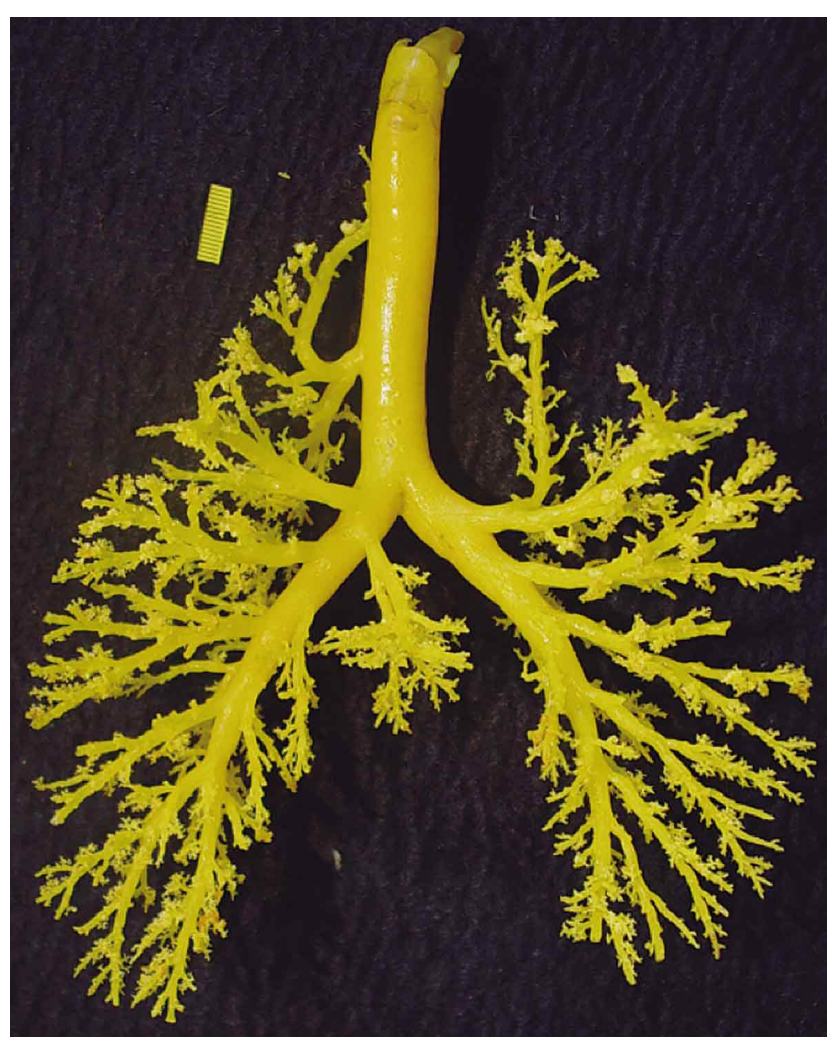

Fig. 5. Metacrilate resin casting of pig bronchial tree $(\mathrm{bar}=1 \mathrm{~cm})$.

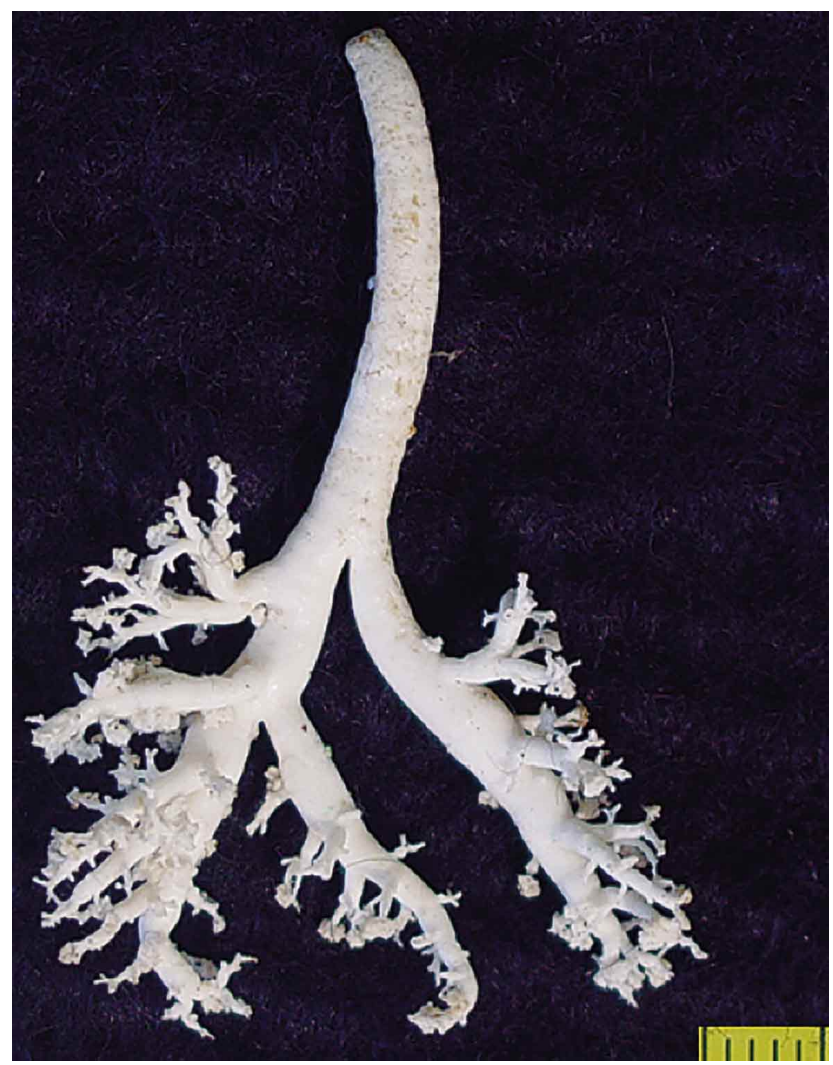

Fig. 7. Rubber silicon casting of rat bronchial tree $(\mathrm{bar}=1 \mathrm{~cm})$.

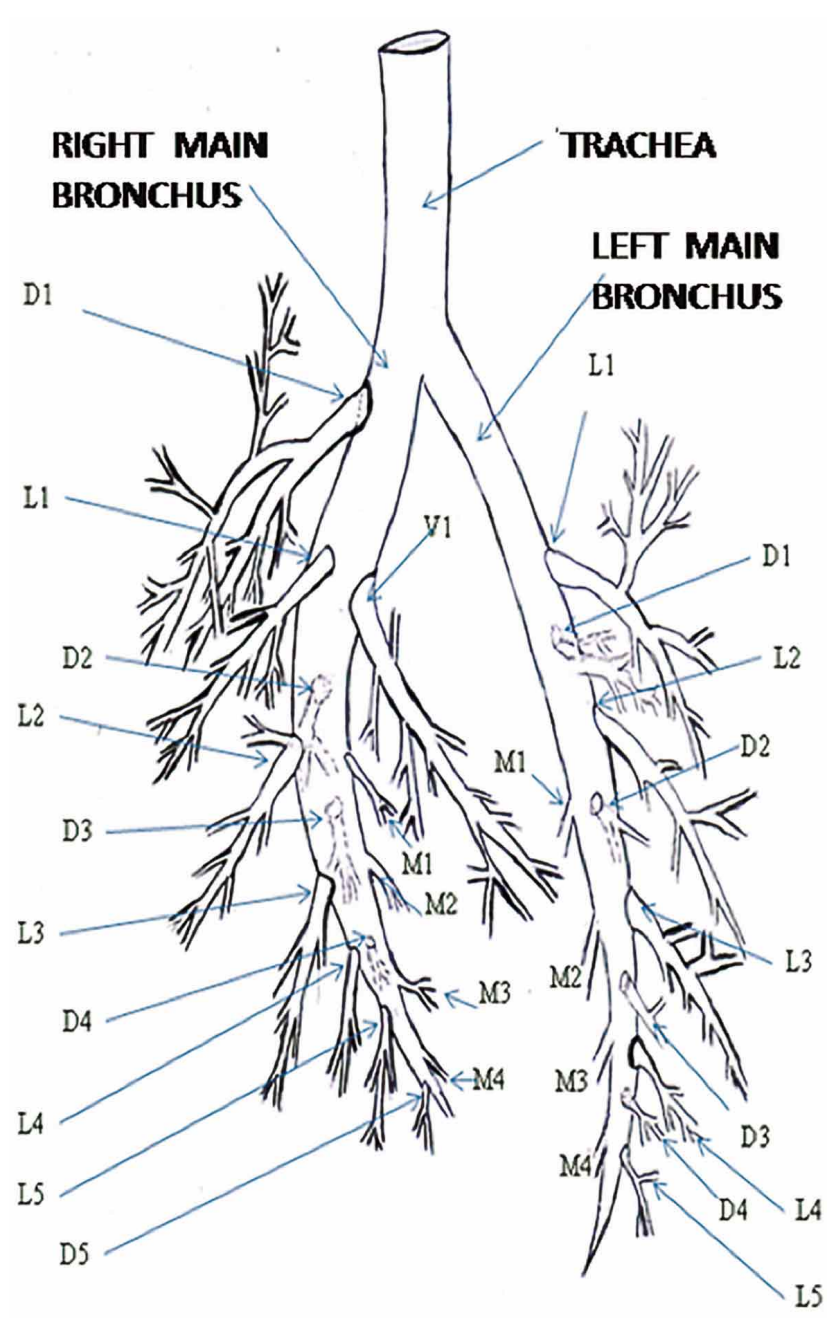

Fig. 6. Scheme and nomencleture of the rat bronchial tree. Right: Main bronchus, Lateral 11, 12, 13, 14, 15, Dorsal d1, d2, d3, d4, d5, Medial m1, m2, m3, m4 and Ventral v1. Left: Main bronchus, Lateral 11, 12, 13, 14, 15, Dorsal d1, d2, d3, d4 and Medial m1, m2, $\mathrm{m} 3, \mathrm{~m} 4$.

The linear relationship of tracheal diameters was 1.2 times larger in human than the pig and 6.7 times larger than the rat; the pig tracheal diameter was 5.6 times larger than the rat. Right bronchia diameters was respectively $1.4-8.6$ - 5.9 and left bronchia was respectively $1.2-9.5-7.7$.

Allometric study was performed to verify correlation between body mass and tracheobronchial diameters. Data were transformed in logarithms and regressed with minimum square technique. Regression and linear correlation shows that was no correlation between body mass, trachea and main bronchia. 
Relations between body mass to trachea and bronchia between the studied specimens are presented in Figures 8, 9 and 10. Relationship of the trachea is larger in the rat, followed by pig and lastly in human and the differences are statistically significant. The same occurred in right bronchus. As the left bronchus there were no differences between rat and pig, though human was different from rat and pig.

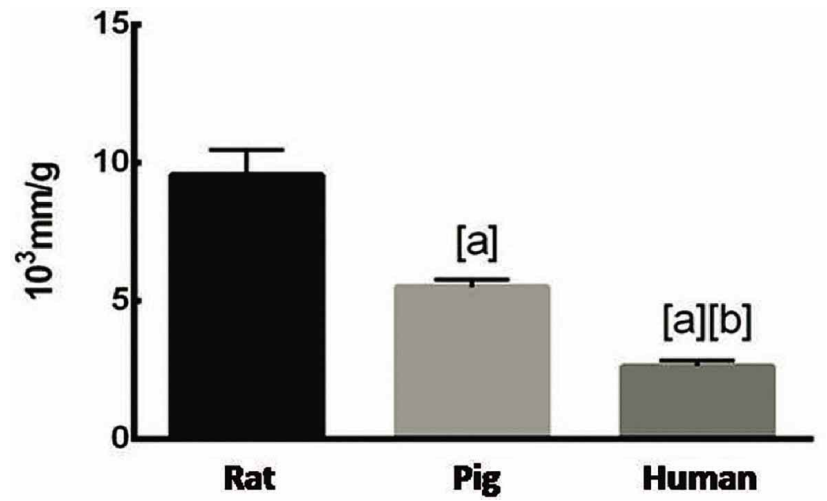

Fig. 8. Graphic of relationship between trachea and body mass. [a] $\neq$ rat; $[\mathrm{b}] \neq$ pig $(\neq$ means different)

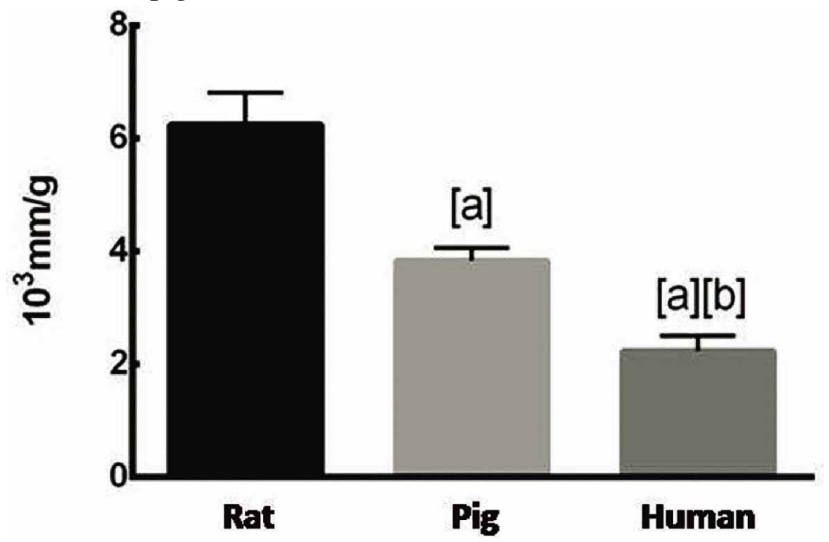

Fig. 9. Graphic of relationship between right bronchus and body mass. a $\neq \neq$ rat; $[b] \neq$ pig.

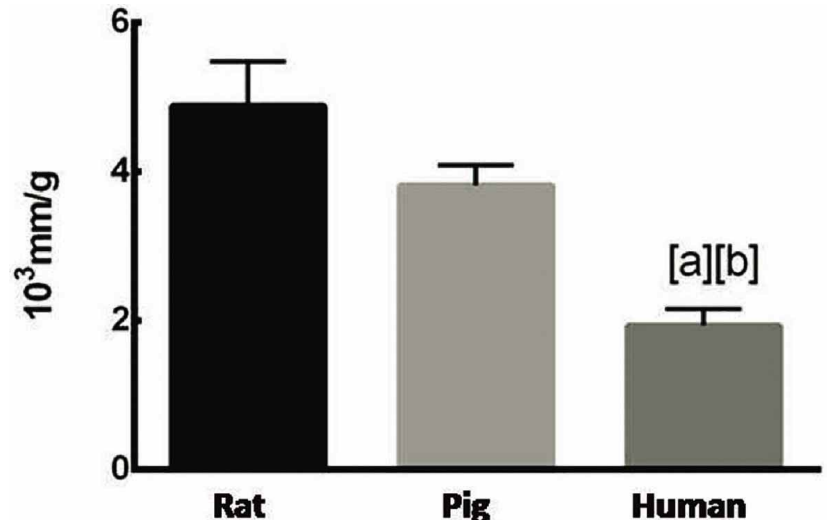

Fig. 10. Graphic of relationship between left bronchus and body mass. a $\neq$ rat; $[\mathrm{b}] \neq$ pig.
Tables II, III and IV show the results and variance analysis of measures followed by Sidak's multiple comparisons tests.

Table I. Diameters media, standard deviation of trachea and main bronchia $(\mathrm{mm})$ and body mass $(\mathrm{kg})$.

\begin{tabular}{llll}
\hline & Human & Pig & Rat \\
\hline Trachea & $19.8 \pm 4.06$ & $16.04 \pm 2.75$ & $2.85 \pm 0.85$ \\
Right bronchus & $16.12 \pm 5.51$ & $11.09 \pm 2.31$ & $1.87 \pm 0.56$ \\
Left bronchus & $13.8 \pm 4.73$ & $11.19 \pm 2.31$ & $1.45 \pm 0.53$ \\
Body mass (kg) & $70 \pm 7$ & $30 \pm 3$ & $0.300 \pm 0.30$ \\
\hline
\end{tabular}

Table II. Mean difference of trachea diameters/body mass, variance analysis of measures and Sidak's multiple comparisons tests.

\begin{tabular}{lcccc}
\hline Trachea & Mean Diff & $95 \% \mathrm{Cl}$ of diff & Significant & Summary \\
\hline rat x pig & 4.070 & 1.834 to 6.306 & yes & $* * *$ \\
rat x & 6.923 & 4.832 to 9.015 & yes & $* * * *$ \\
pig x & 2.853 & 0.6176 to 5.089 & yes & $* *$ \\
\hline
\end{tabular}

Table III. Mean difference of right bronchus diameters/body mass, variance analysis of measures and Sidak's multiple comparisons tests.

\begin{tabular}{lcccc}
\hline $\begin{array}{l}\text { Right } \\
\text { bronchus }\end{array}$ & $\begin{array}{c}\text { Mean } \\
\text { Diff }\end{array}$ & $95 \%$ Cl of diff & Significant & Summary \\
\hline rat x pig & 2.406 & 0.8761 to 3.936 & yes & $* *$ \\
rat x human & 4.004 & 2.573 to 5.436 & yes & $* * * *$ \\
pig x & 1.598 & 0.0681 to 3.128 & yes & $*$ \\
\hline
\end{tabular}

Table IV. Mean difference of left bronchus diameters/body mass, variance analysis of measures and Sidak's multiple comparisons tests.

\begin{tabular}{lcccc}
\hline $\begin{array}{l}\text { Left } \\
\text { bronchus }\end{array}$ & $\begin{array}{c}\text { Mean } \\
\text { Diff }\end{array}$ & $95 \% \mathrm{Cl}$ of diff & Significant & Summary \\
\hline rat x pig & 1.068 & $-0,507$ to 2.643 & no & $\mathrm{n} \mathrm{s}$ \\
rat x human & 2.947 & 1.473 to 4.420 & yes & $* * *$ \\
pig x & 1.879 & 0.3036 to 3.455 & yes & $*$ \\
\hline
\end{tabular}

\section{DISCUSSION}

A comparative analysis of the bronchial tree geometry revealed that man has a standard dichotomous bifurcation, pig and mouse standard monopodial branching. Bronchial tree asymmetry explains airway diameters in any branching level and can determine air flux in the lung (Horsfield; Majumdar et al., 2005; Lee et al., 2007). 
The differences in the lung anatomy of the studied species require a nomenclature for the bronchial trees because there is no correspondence between man and the studied species. The anatomy of the lungs and bronchia is specific for each species, for example the tracheal bronchus in the pig and accessory lobe in both pig and rat. Usual terminology was used for man (Williams) and for pig and rat terminology proposed by Nakakuki $(1975,1983)$.

Since rats and pigs are animal models used in experiments in respiratory physiology, some caution is necessary to transpose obtained data to human respiratory physiology. Thus, comparison between bronchial trees of those mammals must be considered in addition to anatomical aspects, air flow mechanics, body mass, posture and behavior.

Rats and pigs present a quadruped posture meaning that the body, lungs and airways are disposed in a horizontal fashion although man as a biped has a vertical body and airways disposition during most of the day. This may be associated to monopodial and dichotomous branching of the studied bronchial tree and also to the airways diameters.

The linear measures showed that as higher is body mass larger are the airways diameters. The tracheal diameters relationship was 1.2 times larger in human than the pig and 6.7 times larger than the rat; the pig tracheal diameter was 5.6 times larger than the rat. The opposite is verified when diameters of tracheobronchial tree were compared using allometry to equilibrate body mass differences to get corrected anatomical parameters (Lindstedt \& Schaeffer, 2002). The relationship between the diameters and body weights of the trachea and right bronchus in rats was shown to be larger than pigs and pigs larger than man, differences are statistically significant. The relationship between body weights and diameters of the left bronchus showed no difference between the rat and pig, while man diameters were different from rat and pig. The anatomy of the bronchial tree adapts to efficiency of the air flow where the respiratory rate is greater in small mammals. This assumption was verified in a study of the dependency of body dimensions and conductive bronchial tree in four closely related species of rodents with similar body proportions, locomotion habits, and diet but differing mainly in adult body weight. Airways diameters showed a negative allometric correlation with body weight, indicating a resistance decay of small animals airways when compared with bigger ones (Valerius). This is compensating by a higher respiratory frequency.

Respiratory frequency is higher in small mammals when compared with larger mammals (Lindstedt, 1984). There is a drastic breathing frequency decay with body weight increase, ventilation parameters in rat is 5.74 times higher than in man (654.4 and $114 \mathrm{ml} / \mathrm{kg}$-min respectively) and oxygen uptake in rat is 4 times higher than man (Lindstedt \& Schaeffer). Diffusing capacity for oxygen ( $\mathrm{ml} / \mathrm{kg}$-min-torr) of rat is 1.2 times higher than man, showing that lung alveolar air blood changing is similar (Gehr et al., 1981).

Understanding precise geometric representations of airways structures is important to morphology, physiology and lung diseases studies, moreover when models are elaborated by experimental studies with animal systems.

\section{ACKNOWLEDGMENTS}

CAPES for financial support to Adilson Monteiro, Allometry and statistical analysis was performed with the help of Carlos Alberto Mandarim de Lacerda from Universidade Estadual do Rio de Janeiro, Brazil.

MONTEIRO, A. \& SMITH, R. L. Arquitectura del árbol bronquial en mamíferos de diferentes masas corporales Int. Int. J. Morphol., 32(1):312-318, 2014

RESUMEN: La anatomía de los espacios aéreos en los pulmones de mamíferos constituyen el árbol bronquial cuya disposición es asociada a la dinámica del flujo aéreo. Moldes obtenidos de los pulmones de humanos, cerdos y ratones fueron estudiados para analizar las posibles diferencias de las arquitecturas de los árboles bronquiales en mamíferos de diferentes dimensiones y posturas. Los espacios aéreos fueran llenados con polímeros por la tráquea y posterior corrosión con ácido. Los diámetros de la tráquea y de las principales divisiones de los bronquios fueron medidos y relacionados con las masas corporales por medio de alometría. Los resultados revelaron uno patrón dicotómico en los moldes de humanos y un patrón monopodial en los animales. La relación alométrica determinço que la tráquea es mayor en los ratones, seguidos de los cerdos y por último en los humanos, las diferencias fueran estadísticamente significativas. Lo mismo ocurrió en el bronquio derecho en cambio en el bronquio izquierdo no hubo diferencia entre el cerdo y el ratón. La relación linear entre los diámetros de la tráquea fue 1,2 mayor en el humano comparada con el cerdo y 6,7 mayor que el ratón, el diámetro de la tráquea del cerdo fue 5,6 mayor que el ratón. La posición cuadrúpede del cerdo y del ratón es vinculada a una vía aérea horizontal en cuanto a que la posición erecta en humanos corresponde a una vía aérea vertical. Los grandes mamíferos muestran menor frecuencia respiratoria que los pequeños mamíferos. Mamíferos con masas corporales pequeñas, medias y grandes con diversas posturas y hábitos fueron comparados mostrando diferencias morfológicas en los árboles bronquiales así como diferentes correlaciones alométricas entre animales cuadrúpedos y humanos bípedos.

PALABRAS CLAVE: Bronquio; Anatomía; Humano; Cerdo; Ratón. 


\section{REFERENCES}

De Backer, J. W.; Vos, W. G.; Burnell, P.; Verhulst, S. L.; Salmon, P.; De Clerck, N. \& De Backer, W. Study of the variability in upper and lower airway morphology in Sprague-Dawley rats using modern micro-CT scan-based segmentation techniques. Anat. Rec (Hoboken), 292(5):720-7, 2009.

Dondelinger, R. F.; Ghysels, M. P.; Brisbois, D.; Donkers, E.; Snaps, F. R.; Saunders, J. \& Devière, J. Relevant radiological anatomy of the pig as a training model in interventional radiology. Eur. Radiol., 8(7):1254-73, 1998.

Dyce, K. M.; Sack, W. O. \& Wensing, C. J. G. Tratado de anatomía veterinaria. Rio de Janeiro, Guanabara Koogan, 1997.

Einstein, D. R.; Neradilak , B.; Pollisar, N.; Minard, K. R.; Wallis, C.; Fanucchi, M.; Carson, J. P.; Kuprat, A. P.; Kabilan, S.; Jacob, R. E. \& Corley, R. A. An automated self-similarity analysis of the pulmonary tree of the Sprague-Dawley rat. Anat. Rec. (Hoboken), 291(12):1628-48, 2008.

Federative Committee on Anatomical Terminology. International Anatomical Terminology. Stuttgart, Georg Thieme Verlag, 1998.

Gehr, P.; Mwangi, D. K.; Ammann, A.; Maloiy, G. M.; Taylor, C. R. \& Weibel, E. R. Design of the mammalian respiratory system. V. Scaling morphometric pulmonary diffusing capacity to body mass: wild and domestic mammals. Respir. Physiol., 44(1):6186, 1981.

Hare, W. C. D. Sistema respiratório do suíno. In: Getty R. (Ed.). Anatomia dos animais domésticos. Rio de Janeiro, Guanabara Koogan, 1986.

Hayward, J. \& Reid, L. M. Observations on the anatomy of the intrasegmental bronchial tree. Thorax, 7(1):89-97, 1952.

Horsfield, K. Diameters, generations, and orders of branches in the bronchial tree. J. Appl. Physiol., 68(2):457-61, 1990.

Lee, J. W.; Kang, M. Y.; Yang, H. J. \& Lee, E. Fluid-dynamic optimality in the generation-averaged length-to-diameter ratio of the human bronchial tree. Med. Biol. Eng. Comput., 45(11):1071-8, 2007.

Linstedt, S. L. Pulmonary transit time and diffusing capacity in mammals. Am. J. Physiol., 246(3 Pt. 2):R384-8, 1984.

Lindstedt, S. L. \& Schaeffer, P. J. Use of allometry in predicting anatomical and physiological parameters of mammals. Lab. Anim., 36(1):1-19, 2002.

Maina, J. N. \& Gils, V. P. Morphometric characterization of the airway and vascular systems of the lung of the domestic pig, Sus scrofa: comparison of the airway, arterial and venous systems. Comp. Biochem. Physiol. A Mol. Integr. Physiol., 130(4):781-98, 2001.
Majumdar. A.; Alencar, A. M.; Buldyrev, S. V.; Hantos, Z.; Lutchen, K. R.; Stanley, H. E. \& Suki, B. Relating airway diameter distributions to regular branching asymmetry in the lung. Phys. Rev. Lett., 95(16):168101, 2005.

Mouton, W. G.; Pfitzner, J.; Bessell, J. R. \& Maddern, G. J. Bronchial anatomy and single-lung ventilation in the pig. Can. J. Anaesth., 46(7):701-3, 1999.

Nakakuki, S. The new interpretation of bronchial tree. Proc. Japan. Acad., 51:342-6, 1975.

Nakakuki, S. The bronchial tree and blood vessels of the rat lung. Anat. Anz., 154(4):305-12, 1983.

Nakakuki, S. Bronchial tree, lobular division and blood vessels of the pig lung. J. Vet. Med. Sci., 56(4):685-9, 1994.

Patra, A. L. Comparative anatomy of mammalian respiratory tract: the nasopharyngeal region and the tracheobronchial region. $J$. Toxicol. Environ. Health, 17(2-3):163-74, 1986.

Valerius, K. P. Size-dependent morphology of the conductive bronchial tree in four species of myomorph rodents. J. Morphol., 230(3):291-7, 1996.

Wang, P. M. \& Kraman, S. S. Fractal branching pattern of the monopodial canine airway. J. Appl. Physiol., 96(6):2194-9, 2004.

Weibel, E. R. Fractal geometry: a design principle for living organisms. Am. J. Physiol., 261(6 Pt. 1):L361-9, 1991.

Weibel, E. R. \& Gomez, D. M. Architecture of the human lung. Use of quantitative methods establishes fundamental relations between size and number of lung structures. Science, 137(3530):577-85, 1962.

Williams, P. L. Gray's Anatomy. 38 a ed. New York, Churchill Livingstone, 1995.

Yeh, H. C.; Schum, G. M. \& Duggan, M. T. Anatomic models of the tracheobronchial and pulmonary regions of the rat. Anat. Rec., 195(3):483-92, 1979.

Correspondence to:

Ricardo Luiz Smith

Universidade Federal de São Paulo

Brazil

phone $55-11-55764261$

Email: rlsmith@unifesp.br

Received: 20-10-2013

Accepted: 11-02-2014 